1 African Union, Africa Vaccine Delivery Alliance

Cite this as: $B M J 2021 ; 375: \mathrm{n} 2848$ http://dx.doi.org/10.1136/bmj.n2848 Published: 19 November 2021

OPTIONS FOR A GLOBAL PANDEMIC TREATY

\title{
Unless we address the inequity in global health, then the world will not be prepared for the next pandemic
}

\section{Ayoade Olatunbosun-Alakija chair}

The global health infrastructure is broken. We are attempting to put plasters on multiple compound fractures-a useless and wasteful exercise. This failure to act is not about resources, or a lack thereof, but rather a deep inequality in society, one which predates this current pandemic. It is the lynchpin that has brought us to our knees. The suggestion that there is a lack of vaccines or tools to adequately address the pandemic worldwide is a myth perpetuated by the global North in order to avoid taking accountability for the hoarding and price gouging of vaccines. We exist in a divided world, one which is continuing to fragment along the lines of bias and inequity. Enough is enough.

There is an urgency for world leaders to take responsibility for the systemic change required to achieve global pandemic preparedness and bring an end to this ongoing covid-19 humanitarian crisis. Launching an equitable pandemic response needs no justification, and no rehearsal. It is long past time to act, and in that vein, we in the global South must also stand up and take accountability for our part in this.

From my perspective, here in Abuja, Nigeria, what we desperately need is not only political leadership, but the courage to address the root cause of the situation we find ourselves in-systemic inequality. This pandemic is a once in a 100 year event which requires a once in a 100 year level of global solidarity and cooperation. There is no sense in addressing the symptoms without first treating the disease.

In a session with several leaders in the global health community at the World Health Summit in October in Berlin, we called, and do so again now, for a summit to bring together our global heads of state to bring this action forward. More so, what will ensure that our world comes together is a global pandemic treaty, one which is led by the global South, one which provides a wholly inclusive solution to the current situation. This is a first step in implementing the call to action of the Global Preparedness Monitoring Board (GMPB) in their latest report to strengthen global governance. ${ }^{1}$ What is required is a deep dialogue, one to bring the leaders of the global South to the table in an attempt to ensure an inclusive conversation. We are calling for a summit in Africa, convened by Africa, to hear the world speak as one for the first time. This is an opportunity to kickstart transformational change and begin the process of untangling the inequality in global health.

There are still questions surrounding this pandemic. Who will hold leaders and organisations accountable? Who will hold those in power to account for hoarding vaccines and refusing to deliver them to those in desperate need? We cannot afford to wait for the global North to discover its morality. We must act now to take control of our destiny-indeed, we must act now to save our own lives.

In Abuja next year at the PortsToArms Summit: Vaccine Equity, Delivery, and Manufacturing, we hope to begin to shift the balance of that power, to break open pre-existing alliances, and ensure that everyone has a seat at the table. This pandemic affects us all, and will not end for one of us, until it ends for all of us.

We hope the world will join us. Our collective global health security depends on this. We know what must be done, and we know how. All that remains is to determine who is willing to step up, and if they will do so before it is too late.

Competing interests: None declared.

This article is part of a collection of articles on a global pandemic treaty. The collection was proposed by the Global Health Centre at the Graduate Institute. The BMJ edited and made the decisions to publish the articles. Article handling and open access fees are funded by a research project at the Global Health Centre, Graduate Institute, Geneva. Kamran Abbasi and Juliet Dobson are the editors for The BMJ.

\section{GPMB. From Worlds Apart. https://www.gpmb.org/docs/li- brariesprovider17/default-document-library/gpmb-annual-report- 2021.pdf?sfvrsn=44d10dfa_9}

This is an Open Access article distributed in accordance with the Creative Commons Attribution Non Commercial (CC BY-NC 4.0) license, which permits others to distribute, remix, adapt, build upon this work non-commercially, and license their derivative works on different terms, provided the original work is properly cited and the use is non-commercial. See: $\mathrm{http}: / /$ creativecommons.org/licenses/by-nc/4.0/. 